\title{
Statutory Central Bank Independence in Taiwan
}

\author{
C. James Hueng \\ Associate Professor of Economics, Western Michigan University \\ 1903 W. Michigan Avenue \\ Kalamazoo, MI 49008-5330, U.S.A. \\ Tel: 1-269-387-5558 E-mail: James.Hueng@wmich.edu \\ $\&$ \\ Fulbright Visiting Scholar \\ Institute for Advanced Studies in Humanities and Social Sciences \\ National Taiwan University \\ Taipei, Taiwan
}

This research is sponsored by the 2009/2010 U.S. Scholar Fulbright Program, the Council for International Exchange of Scholars, U.S.A., and the Foundation for Scholarly Exchange, Taiwan.

\begin{abstract}
This paper critically reviews the Central Bank of the Republic of China (Taiwan) Act and finds that the level of legal independence of the central bank is relatively low compared to the rest of the world. However, Taiwan has been able to combine low inflation with a legally dependent central bank. We provide possible explanations to this low inflation/low independence puzzle in Taiwan and argue that Taiwan should still follow the trend of creating a more independent central bank.
\end{abstract}

Keywords: Central bank independence, Legal CBI Index

\section{Introduction}

Backed by academic research, it is a broad practical consensus that the primary responsibility of the central bank is to assure price stability. The time inconsistency models by Kydland and Prescott (1977) and Barro and Gordon (1983) show that a public-elected monetary authority suffers from an inflationary bias. To reduce this bias, studies such as Rogoff (1985) suggest insulating monetary policy from the political pressures. Since the establishment of this theoretical foundation, a bulk of research has been devoted to the study of central bank independence (CBI). (Note 1)

In the empirical research, whether or not $\mathrm{CBI}$ is responsible for low inflation is still up for debate. On the one hand extensive cross-country studies have suggested that $\mathrm{CBI}$ increases the likelihood of fostering a lower and more stable inflation at no real cost [see for example, Grilli et al. (1991), Cukierman et al. (1992), and Alesina and Summers (1993)]. On the other hand critics find evidence that CBI is an endogenously determined variable, not an exogenous variable that causes low inflation [see for example, Posen (1993), Forder (1996), and Hayo (1998)].

This divergence in opinions, however, does not stop the trend that more and more countries in the world have implemented institutional reforms to grant their central banks more independence over the last two decades. Polillo and Guillen (2005) find that during the 1990's alone, "as many as 17 countries in Eastern Europe and the former Soviet Union made statutory changes toward greater independence; so did 13 countries in Western Europe, 11 countries in Latin America, 9 countries in Africa, and 4 countries in Asia." The culmination of this trend is the European Central Bank established in 1999. Most central banks today enjoy substantially higher levels of independence than twenty years ago.

Disinclined to the trend, the level of legal independence of the Central Bank of the Republic of China (Taiwan), hereafter the $\mathrm{CBC}$, has not changed for several decades. Most of the available indices of CBI refer to the level of independence as specified in the law. The Central Bank of the Republic of China Act, hereafter the CBC Act, was first promulgated in 1935. The structure of the current $C B C$ Act was not established until the first amendment in 
1979. Since then the CBC Act was revised twice in 1997 and 2002. However, the articles being added or amended in these two revisions are not related to the legal dependence of the CBC. Therefore, the statutory dependence of the $\mathrm{CBC}$ has not changed for more than three decades. Based on the most popular CBI index developed by Cukierman, Webb, and Neyapti (1992, hereafter CWN), the CBC had the ninth lowest score in the 1980's among the 72 countries included in that study. This index is updated in Crowe and Meade (2007) for 96 countries at the end of 2003. (Note 2) Based on the updated data, the CBC's CBI index is only higher than that of the Monetary Authority of Singapore (the central bank of Singapore).

Although not following the global trend of granting central bank independence in the laws, Taiwan has been successfully combining low inflation with little legal CBI. The first step this paper takes is to critically review the $C B C$ Act to confirm that the $\mathrm{CBI}$ index for Taiwan in the literature is properly measured. Country-specific studies on $\mathrm{CBI}$ often provide a more accurate index than cross-country studies because legislations relevant to $\mathrm{CBI}$ in addition to the central bank law are usually more carefully reviewed. This study reevaluates the CBC's legal independence by surveying available legal documents in Taiwan that are related to CBI.

To numerically measure the legal CBI, we use the CWN index, which is probably the most comprehensive and popular index in the literature. Other indices, such as those used by Bade and Parkin (1988), Alesina (1988, 1989), Grilli et al. (1991) and Eijffinger and Schaling (1993) can, for the most part, be approximated by subsets of the components of the CWN index. In addition, CWN is one of few studies that include Taiwan in the analysis. Therefore, we are able to review whether there is a misunderstanding on the level of legal independence for the $\mathrm{CBC}$ in the literature.

We only focus on legal independence and leave out the measure of actual independence because the latter is often exposed to subjective explanations. It is well known that de facto independence may often deviate from de jure independence. Such deviations may be significant in developing countries due to poor enforcement of the law, i.e., actual independence is much lower than what is specified in the law. However, this is not our concern because it is often claimed by the $\mathrm{CBC}$ that its de facto $\mathrm{CBI}$ is much higher than de jure CBI. The purpose of this paper is neither to discuss the practical independence enjoyed by the CBC nor to derive the effects of independence on the performance of the Taiwanese economy. Rather, our goal is to study the legal independence of the $\mathrm{CBC}$, with the assumption that improving legal independence helps maintain factual independence and long-run stability.

After confirming the validity of the CBI index for Taiwan in the next section, Section 3 provides possible explanations to the low inflation/low CBI puzzle in Taiwan and argues that Taiwan should still follow the trend of creating a more independent central bank. We then discuss changes on the $C B C$ Act that can increase the statutory independence of the $\mathrm{CBC}$ in Section 4. Section 5 concludes the paper.

\section{Review of the CBC's legal CBI index}

In the most comprehensive study of central bank institutional arrangements, Cukierman, Webb, and Neyapti (1992, CWN) create an index of central bank independence (CBI) based on readings of central bank laws for a large sample of countries, including Taiwan. Only the written information from the charters in various legal dimensions is used. Their index is aggregated from sixteen legal characteristics of central bank charters, which are grouped into four clusters of issues (the followings are directly quoted from Table 1 in $\mathrm{CWN}$ ):

(1) The term of office, appointment, and dismissal of the chief executive officer (CEO) of the central bank: a central bank is more independent if the CEO has a longer term of office and if the government has little legal authority to appoint or dismiss the CEO.

(2) The central bank's authority to formulate and finalize monetary policy: a more independent central bank has a wider authority to formulate monetary policy and is able to resist the government in cases of conflict.

(3) The legal mandate of the central bank to pursue the objective of price stability: a more independent central bank has a higher prominence given to price stability compared with other stated objectives that may conflict with price stability. This variable is usually referred to as the measure of the "conservativeness" of the central banker.

(4) Limitations on the ability of the central bank to lend to the government: a more independent central bank has tighter limits on its lending to the public sector. This cluster encompasses five more detailed variables: (4.1) limitation on nonsecuritized lending; (4.2) limitation on securitized lending; (4.3) who determines the terms of lending (maturity, interest, and amount); (4.4) potential borrowers from the CB; and (4.5) type of limits (maturity, interest, amount, and whether the $\mathrm{CB}$ is prohibited from the primary market of the government securities). 
Eight legal variables are constructed from these four clusters of characteristics (the first three clusters plus five variables in the fourth cluster of characteristics) and then aggregated into the weighted-average index. We proceed with reviewing the articles in the $C B C$ Act that are related to CBI based on the categories used by $\mathrm{CWN}$, and then analyzing the validity of CWN's coding for the CBC.

Cluster (1)-CEO:

Term of office: Based on Article 5 in the $C B C$ Act, the governor of the Board of Directors is appointed for a term of five years. This gives a numerical code of 0.5 , which is the same as that assigned by CWN.

Who appoints CEO? Based on Article 5, the governor of the CBC is an ex officio member of the Executive Board of Directors, members of which are nominated by the Executive Yuan and appointed by the President of the Republic. Therefore, strictly speaking, the CEO is appointed by the president alone, which earns a score of zero. Even if we take account for the input from the Executive Yuan in the decision, the CEO is still appointed by "one or two members of the executive branch" (the president and the Premier of the Executive Yuan). CWN assign a score of 0.5 (Legislature appoints CEO), which is apparently a mistake. The CWN index for Taiwan in this category is overvalued.

Dismissal: There is no provision for dismissal of the governor of the CBC. Therefore, the score for this variable is one, which is the same as that assigned by $\mathrm{CWN}$.

May CEO hold other offices in government? There is no rule against CEO holding another office. Thus, the score for this variable is zero, consistent with that assigned by CWN.

\section{Cluster (2) - Policy formation:}

There are three legal variables in this cluster: (i) Who formulates monetary policy? (ii) Who has final word in resolution of conflict? and (iii) Role in the government's budgetary process. CWN assign a score of zero to all three variables for the $\mathrm{CBC}$. This numerical coding is understandable because according to Article 1 of the $C B C$ $A c t$, the $\mathrm{CBC}$ is "a government bank and an agency under the Executive Yuan." Therefore, it seems that the executive branch of the government has the power to coordinate its fiscal and monetary policies.

However, Article 6 of the $C B C$ Act indicates that the Board of Directors of the $\mathrm{CBC}$ has the power "to examine policies concerning money, credit and foreign exchange." In addition, as mentioned above, the directors have tenure of five years, which is longer than that of the President of the Republic. Therefore, the CBC should enjoy certain degree of independence in monetary policy making. But this independence is not complete because Article 5 of the $C B C$ Act states ". . . the Minister of Finance and the Minister of Economic Affairs shall be ex officio directors and executive directors." That is, the government has two representatives, whose term is determined by the Executive Yuan, in the Board of Directors of the CBC. For the variable "Who formulates monetary policy?" the coding is 1 for "Bank alone" and 0.67 for "Bank participates, but has little influence." Therefore, a better coding should be in between these two classifications, which is not provided by CWN.

For the second variable (Who has final word in resolution of conflict?), the $C B C$ Act does not contain a provision on the resolution of conflict. Based on Article 10 of the Rules and Regulations of the Board of Directors Meetings, the decision of the board is determined by a majority vote of directors in attendance (the quorum required for the meetings is more than one half of the directors). Since there are eleven to fifteen directors and only two of them are representatives from the government, the directors with tenures have majority votes. With this alternative interpretation, we would assign a numerical coding of 1 to the $\mathrm{CBC}$.

\section{Cluster (3) - Objectives:}

Article 2 of the $C B C$ Act states "The primary objectives of the Bank's operations shall be: 1 . To promote financial stability; 2 . To guide sound banking operations; 3 . To maintain the stability of the internal and external value of the currency; 4 . To foster economic development within the scope of the above objectives." Therefore, the numerical coding for the $\mathrm{CBC}$ in this cluster should be 0.40 ("Price stability is one goal, with potentially conflicting objectives, such as full employment"). CWN instead assign a score of 0.6 ("Price stability is one goal, with other compatible objectives, such as a stable banking system") to the CBC. Since the potentially conflicting objective of fostering economic development is only in effect within the scope of the other three objectives, the numerical coding by CWN is also acceptable.

Cluster (4) - Limitations on lending to the government:

There are eight legal variables under this cluster. The only article in the $C B C$ Act that is related to the government financing is Article 26: "The Bank may, in the light of financial conditions, purchase and sell in the open market the bonds issued or guaranteed by the government ..." and no condition of lending is specified in 
the law. (Note 3) Together with the fact that the CBC is defined as a national bank and a government agency, it is not surprised that CWN assign zero to all but one variable for the CBC. The only nonzero score is for the variable "potential borrowers from the bank," which is not clearly defined in the laws but, since the CBC is a national bank, should include all levels of government and public enterprises. Therefore, the score of 0.33 assigned by $\mathrm{CWN}$ is proper.

However, there is a law that is related to another variable in this cluster ("central bank prohibited from buying or selling government securities in the primary market?") and may be ignored by CWN. Article 9-1 in the Central Government Development Bonds and Loans Act states that "The Central Bank of China ("the Central Bank") may not assume the responsibility as issuer of the government bonds or act as lender referred herein. However, its eligibility to be the issuer and lender that are presented by the Executive Yuan and voted in favor by the Legislative Yuan shall lift the restrictions." Therefore, this law can be interpreted as the restriction for the CBC to purchase government bonds from the primary market.

In sum, even though there is improper coding for the $\mathrm{CBC}$ by $\mathrm{CWN}$, it is not far away from alternative coding that we provide. That is, the legal independence index is indeed very low for the $\mathrm{CBC}$ based on the current $C B C$ Act.

\section{Low Inflation/Low CBI Puzzle in Taiwan}

Although the legal independence index is very low for the CBC, inflation in Taiwan has been well under control. Cover, Hueng, and Yau (2002) show that the CBC has been very close to conducting optimal policies in controlling inflation. Figure 1 plots the average inflation against the CWN index for Taiwan along with 24 OECD countries during the period 1980-1989. (Note 4) Conventional wisdom predicts a negative slope for this relationship. That is, the higher the CBI index is, the lower the rate of inflation becomes. Taiwan is apparently an outlier of this relationship. The CWN index for Taiwan is only higher than that of Japan, Belgian, and Norway. However, Taiwanese inflation rate is among the lowest, at an annual rate of $4.5 \%$. Compared to Mexico, Iceland, Greece, and Portugal, who all have a higher CBI but an annual inflation rate well above $15 \%$, the CBC is very successful in maintaining a low inflation environment.

The same conclusion can be made from Figure 2, which plots the same relationship during a more recent period. The inflation rates are averaged over 2000-2007 and the CBI index is measured as of 2003, obtained from Crowe and Meade (2007). It is clear that most OECD countries have improved their legal CBI, and that the overall inflation rates have been significantly reduced, all below 7\% annually. Even with the lowest CBI index among these countries, Taiwan has enjoyed the trend of "great moderation of inflation" with the other industrialized countries.

How could the legally quite dependent CBC maintain a relatively low inflation over the years? Does the observation above imply that there is no need for an independent central bank in Taiwan? This paper offers possible explanations to the first question and argues that Taiwan should still follow the trend of creating a more independent central bank. The perception of Taiwan being an outlier in the above figures arises from a simple correlation between inflation and CBI. Studies against this link argue that CBI is not the only determinant of inflation. Therefore, this paper tries to provide explanations to this low $\mathrm{CBI} /$ low inflation puzzle by surveying this literature for reasons resulting in low inflation in Taiwan.

The first possible explanation is that the $\mathrm{CBC}$ is actually much more independent than specified in the laws. This is, however, hard to justify because the actual independence is unobservable and often exposed to subjective explanations. More importantly, higher de facto independence is not a legitimate excuse for not having de jure independence. De facto independence can easily be removed if it is not protected by the laws. Therefore, even if the $\mathrm{CBC}$ has indeed enjoyed independence in the past few decades, legal independence is still in need to preserve the factual independence.

An alternative mechanism to CBI for controlling inflation is to peg the domestic currency to that of a major trade partner who has a reputation of low inflation. This is a reasonable explanation of the result in Figure 1. During the 1980's, Taiwan could anchor domestic price levels by pegging the New Taiwan dollar (NTD) to the U.S. dollar. By "delegating" her monetary policy to the U.S., Taiwan had basically identical inflation rate to that of the U.S. during the 1980's.

This alternative mechanism, however, is no longer available to Taiwan. Pressure from the U.S. to appreciate the NTD is part of the reasons for the deflationary spiral after the 1980's. After the Asian financial crisis in 1997-1998, the IMF has requested Asian member countries to float their exchange rates. Although Taiwan is not a member of the IMF, the recent financial liberalization in Taiwan has made her economy more exposed to 
external shocks from the global financial market. Without a fix exchange rate, an independent central bank is even more important than ever because a low degree of CBI allows politically motivated depreciations. Politicians have electoral motivations to delay politically costly depreciations until after an election [Cermeño, Grier, and Grier (2010)].

In addition, with an independent central bank, Taiwan can shelter herself from the critics of her exchange rate policy. Baines (2001) finds that there is a negative relationship between foreign exchange intervention and CBI. That is, a dependent central bank has the reputation of intervening the foreign exchange market for the government. Kuttner and Posen (2001) show that CBI is associated with a more stable exchange rate. Therefore, legal independence serves as a signal to trade partners that exchange rate movements (or even foreign exchange interventions) are aiming at the goal of low inflation, rather than being politically manipulated and market distorting.

The original argument for an independent central bank is to avoid inflation bias generated by political business cycles. Therefore, it is intuitive to look into the incentives for the Taiwanese government to inflate the economy. Walsh (1997) provides an argument that may help explain the low inflation/low CBI puzzle in Taiwan. He argues that a higher natural rate of unemployment increases the incentive to engineer an economic expansion and therefore, raises the inflation bias. Groenewold and Tang (2004) estimate the natural rate of unemployment for Taiwan and find that it ranges from $2.1 \%$ to $2.9 \%$ during the period $1982-2000$, which is probably only half of that of the United States. Therefore, with a low natural rate of unemployment, and thus a low incentive to inflate, the Taiwanese government might be able to maintain a low inflation reputation without delegating monetary policy to an independent central bank.

However, according to a research in the Directorate General of Budget, Accounting and Statistics of the Executive Yuan, the natural rate of unemployment in Taiwan has been increasing over the past decade (over 3\% in 2002). (Note 5) Therefore, with the incentives to inflate getting higher, a more independent monetary policymaker becomes more important.

Another explanation of the low inflation/low CBI puzzle can be found in the political science literature. It is argued that delegation is not necessary if policies are controlled by a long-lived government, especially a conservative government. This government can focus on long-run growth and has no incentive to create political business cycles to inflate the economy. Before 2000, Taiwan is basically ruled by one party - the KMT, a conservative party. With a high possibility of reelection, the government is capable of maintaining low inflation even without delegating monetary policy to an independent central bank.

This hypothesis is supported by Figure 3, which plots the growth rates (from the same quarter a year ago) of Taiwanese government expenditure/GDP ratio from 1980Q1 to 2008Q1. The vertical bars indicate the quarters where there is a national election. (Note 6) If political business cycles exist in Taiwan, we would expect this ratio to grow higher right before the elections. This is not observed in Figure 3. Indeed, this ratio is declining over the sample period. The average growth rate is $-2.5 \%$ in the election quarters; the one-quarter-ahead average is $-4.9 \%$; the two-quarter-ahead average is $-2.0 \%$; the three-quarter-ahead average is $-2.7 \%$; and the four-quarter-ahead average is $-1.2 \%$. There is no sign of political business cycles in Taiwan.

However, starting from the 1990's the political system in Taiwan has undergone significant changes and moved toward a two-party system. Partisan turnovers are expected to be the norm in the future. A potential threat of politically induced inflation by governments trying to improve their reelection chances cannot be ignored. Because of lower reelection probabilities, the maintenance of low inflation requires that monetary policies be delegated to a more independent central bank. Therefore, a central bank free from political contingencies is in urgent need.

The low inflation in Taiwan may also be explained by an argument provided by Romer (1993), who states that the incentive to inflate will be smaller in an open economy. Since real exchange rate depreciation hurts a more opened economy, the benefit of inflating the economy, which causes real depreciation, is a decreasing function of the degree of openness. Campillo and Miron (1997) show that the degree of openness is an important factor in explaining inflation. Taiwan is well known as an open economy (see Sachs and Warner's "Trade Openness Indicators" - http://www.cid.harvard.edu/ciddata/warner_files/sachswarneropen.xls). Gwartney, Lawson, Park, and Skipton (2001) build a measure of "Trade Openness Index" and rank Taiwan seventeenth among 91 countries in the study during the period 1980-1998. Therefore, the incentive to inflate is relatively low in Taiwan.

However, in today's world, CBI becomes even more important for open economies. CBI is frequently associated with the push for economic and financial globalization. According to the conventional economic wisdom, an 
integrated world market can operate more successfully if there is a high degree of institutional convergence. CBI is in particular an institutional design that is required for a stable international financial system. For example, an independent central bank has become one of the conditions for the member countries to safeguard resources from the IMF. Only an independent central bank is able to show that its commitment to price stability is credible. Therefore, CBI becomes a symbol of group membership. Facing the demand and pressure of globalization, Taiwan is in a critical position to improve her institutional design so as to catch up with the global trend of pursuing a higher level of CBI.

\section{Moving toward a higher level of legal independence}

Due to the rapid political and economic development in the past few decades in Taiwan, an independent central bank has become an undeniable necessity for the future of the economy. Based on the analysis in Section 2, it can be seen that there exist conflicts in the Central Bank of the Republic of China Act. On the one hand the CBC enjoys certain degree of independence because its directors of the Board are protected by tenure. On the other hand, however, the fact that the $\mathrm{CBC}$ is a government agency under the executive branch of the government overshadows this independency. In particular, being an agency under the Executive Yuan, the CBC's budget is under the supervision of the government. Any attempt to resist inflationary public debt is not credible. Therefore, the first step to improve $\mathrm{CBI}$ is to make the $\mathrm{CBC}$ an independent agency outside the executive government so that it can function autonomously without the supervision of the government.

In the followings, we discuss, using again the CWN clusters, the possible changes in the CBC Act that should improve its statutory independence.

Cluster (1) - CEO:

CBI is characterized by insulation from influences and pressures by public-elected government officials. The supposedly nonpartisan and depoliticized approach to policy making is the core idea. However, the board members of central banks are usually appointed by the executive branch of the government. Therefore, central banks that are formally independent can still be influenced politically via the appointment procedure.

To be free from political contingencies, the members of the Board of Directors should serve for longer terms than that of the government executives who appoint them. In Taiwan, it is the President of the Republic who appoints the members of the Board of Directors of the CBC. The term of Taiwanese presidents is four years, and any president can be re-elected once. Therefore, the ideal term of office for the $\mathrm{CBC}$ directors is longer than eight years. A long tenure for the monetary policy makers is also a necessary design because the virtue attributed to $\mathrm{CBI}$ is that it helps to pursue the objective of long-term price stability. Long tenures make policies more consistent and reduce the volatility of the policy shocks due to turnovers of office.

To be further immune from political pressures, the directors should serve staggered terms so that any president does not have the opportunity to appoint the majority of the board members of an independent central bank. Furthermore, if the president cannot appoint the majority of the board members, electing the governor of the central bank by the board members further reduces the political influence from the executive government. This way of CEO appointment also reduces the degree of tenure overlaps between the central bank governor and the political authorities.

There is no rule against the CBC governors to hold another office in the government. Indeed, it has happened before. As to the board members, the Minister of Finance and the Minister of Economic Affairs are ex officio directors and executive directors. These clearly show the political influence of the government on the CBC. Therefore, building rules in the laws that prohibit the executive government to appoint a minister of the government to the central bank is necessary for a legally independent CBC.

\section{Cluster (2) - Policy formation:}

Recall that there are three legal variables in this cluster: (i) Who formulates monetary policy? (ii) Who has final word in resolution of conflict? and (iii) Role in the government's budgetary process. Politicians have the intention to manipulate policy instruments to improve their electoral prospects or to respond to the preferences of their own party. To avoid politically induced price volatility, one of the simplest solutions is to delegate monetary policy away from the politicians. If governments are not able to set monetary policy, neither are they able to pursue political business cycles using this instrument. Therefore, revising the $C B C$ Act to make the CBC an independent agency that has sole responsibility for the monetary policy without the supervision of the government is the way to improve the coding in these variables.

Cluster (3) - Objectives: 
A more independent central bank has a higher prominence given to the objective of long-term price stability. Any other stated objective in the law reduces CBI because, once there exists conflict of interests, the central bank faces trade-offs among goals and may generate unnecessary inflation bias.

Recall that the objectives stated in the $C B C$ Act are "1. To promote financial stability; 2. To guide sound banking operations; 3 . To maintain the stability of the internal and external value of the currency; 4 . To foster economic development within the scope of the above objectives." Among these objectives "the stability of the internal value of the currency" is the goal of price stability. The "external value of the currency" is the exchange rate.

The objective of economic development is clearly the goal that hinders the CBI because this is where the government puts pressure on the central bank. It is a consensus that monetary stability is an important key for the long-run economic development. The role that the central bank can play as an agent of development is to create a context of monetary stability. Due to the existence of short-run trade-offs between output and inflation, the specified goal of economic development provides politicians with an alternative interpretation. Governments trying to improve their reelection chances have the intention to induce inflationary shocks that could momentarily boost output. Without the responsibility of short-run economic growth, the central bank can be heralded as a necessary check to self-interested politicians.

For the financial stability and the exchange rate stability, research in the literature has shown that the central bank's monetary policy should not react to asset price movements and financial imbalances over and above their impact on the inflation outlook [e.g., Bernanke and Gertler (1999, 2001), Goodfriend (2002), and Greenspan (2002),]. Therefore, when there is a conflict of interests between maintaining stabilities of asset prices and controlling inflation, putting these objectives in law would complicate the task of the central bank.

More recently, both in academia and in the practice of central banking, there are many supporters of the view that the task of supervising banks should be taken away from the central banks. The separation of supervision from central banking is a feature of the European Central Bank. There are at least three arguments that support this view. First, again, when there is a conflict of interest, the attrition of the bank supervision function to the central bank would damage its anti-inflation credibility. For example, in case of a rising inflation, a central bank with responsibility of supervising the banking system may be reluctant to impose a monetary restriction because it may have negative effects on the banking system.

Second, supervising and regulating the banking system increase the possibility that the banking sector would seek to lobby the government to reduce the central bank's independence. Finally, understanding the behavior of price dynamics and building macroeconomics models to forecast inflation are very complicated tasks and therefore, require full-time specialists in the conducts of monetary policies. The responsibility of regulating and supervising the banking system should be delegated to another group of experts in financial markets who have a thorough understanding of all facets of financial markets, including financial assets and financial market regulations.

In Taiwan, the Financial Supervisory Commission was established in 2004 to take over the responsibility of the supervision of the banking sector. Therefore, the second objective (to guide sound banking operations) can be removed accordingly.

Cluster (4) - Limitations on lending to the government:

A central bank free from political intervention is able to boost fiscal discipline by preventing the governments from engaging in inflationary deficit spending. An independent central bank is barred from lending to the government, thus imposing austerity and stability on the economy. As shown in Section 2, there is basically no limitation on lending to the government specified in the $C B C$ Act. Adding to the fact that the $\mathrm{CBC}$ is defined as a government agency, without having specific restrictions on financing the government makes political inflationary bias very possible.

\section{Conclusion}

Like most of the central banks in the world several decades ago, the Central Bank of the Republic of China (CBC) was established as a government bank, functioning as a development bank that provided funds to government for the financing of public expenditures and addressed balance of payments problems. In the past thirty years, however, economic theories on central banking have attributed significant importance to the concept of credibility of monetary policy and central bank independence (CBI). Nowadays it is widely believed that price stability is the most important monetary policy objective, and that a necessary condition for monetary policy to successfully achieve this goal is the policymaker's credibility of commitments to price stability. Even if it is not conclusive that $\mathrm{CBI}$ is a necessary and exogenous cause of low inflation, it is well accepted that an independent 
central bank with explicit mandate to stabilize inflation is an important institutional device to increase the central bank's credibility and to assure price stability. As a result, most central banks in today's world have substantially higher levels of legal independence than twenty years ago. The role of central banks as a development bank has mostly disappeared. The $\mathrm{CBC}$, however, has not changed its statutory independence for more than thirty years.

This paper critically reviews the Central Bank of the Republic of China Act and finds that the level of legal independence of the $\mathrm{CBC}$ is relatively low compared to the rest of the world. In particular, being a government agency under the Executive Yuan and having no specified restrictions on lending to the government are the key aspects that reveal the dependence of the CBC.

Although Taiwan has been able to combine low inflation with a legally dependent central bank, this paper argues that institutional reforms to grant the $\mathrm{CBC}$ more independence are in urgent need. Domestically, the fast changes in the political system moving toward a two-party system justify the need for a legally independent central bank free from political influences. Partisan turnovers are expected in the future and potential threats of politically induced inflation cannot be ignored.

In addition to the benefit of establishing credibility to the public, a more independent $\mathrm{CBC}$ can help Taiwan signal credibility to the international financial system and boost her status and prestige in the international community. CBI plays an important role in today's global market. Monetary policy convergence across countries is the most effective way to fight financial turbulence in the global markets. To integrate into the global economy and excel in the age of globalization, Taiwan needs to conform to the global standard of CBI. Furthermore, monetary and exchange rate policies controlled by an independent central bank are anti-inflationary and free from the intervention from the politicians. A more independent CBC helps Taiwan reduce the skepticism of foreign observers and increase credibility of her currency in the international exchange markets.

As a final note, in addition to improving its legal independence, the issue of transparency of the CBC cannot be overlooked. In the absence of independence, transparency is not necessary because the conduct of monetary policies is subject to the supervision of the executive government and legislature. Once an independent central bank is established, however, delegation of authority to this non-elected institution should be accompanied by transparency. A transparent central bank communicates its intentions to the public and reduces the public's uncertainty about its policies and goals. Transparency and good communication with the public not only make the monetary policy more effective by anchoring the public's inflation expectations, but also reduce the likelihood that the government may revoke the independence of the central bank for political reasons.

\section{References}

Alesina, A. (1988). Macroeconomics and Politics. NBER Macroeconomic Annual. MIT Press, Cambridge, MA, $13-52$.

Alesina, A. (1989). Politics and business cycles in the industrial democracies. Economic Policy, 8, 57-98.

Alesina, A., Summers, L. (1993). Central bank independence and macroeconomic performance: some comparative evidence. Journal of Money, Credit and Banking, 25, 151-162.

Bade, R., Parkin, M. (1988). Central Bank Laws and Monetary Policy. University of Western Ontario. Manuscript.

Baines, A. C. (2001). Capital mobility, perspective and Central Bank independence: Exchange rate policy since 1945. Policy Sciences, 34(2), 171-193.

Barro, R.J., Gordon, D. (1983). Rules, discretion, and reputation in a positive model of monetary policy. Journal of Monetary Economics, 12, 101-121.

Bernanke, B. and Gertler, M. (1999). Monetary Policy and Asset Price Volatility. Federal Reserve Bank of Kansas City Economic Review, 84(4), 17-51.

Bernanke, B. and Gertler, M. (2001). Should Central Banks Respond to Movements in Asset Prices? American Economic Review, 91(2), 253-257.

Berger, H., de Haan, J., Eijffinger, S.C.W. (2001). Central bank independence: an update of theory and evidence. Journal of Economic Surveys, 15, 3-40.

Campillo, M., Miron, J.A. (1997). Why does inflation differ across countries? In: Romer, C.D., Romer, D.H. (Eds.), Reducing Inflation: Motivation and Strategy. University of Chicago Press, Chicago, 335 - 357.

Cermeño, R., Grier, R. and Grier, K. (2010). Elections, Exchange Rates and Reform in Latin America, Journal of Development Economics, forthcoming. 
Cover, J. P., Hueng, C. J. and Yau, R. (2002). Are Policy Rules Better than the Discretionary System in Taiwan? Contemporary Economic Policy, 20 (1), pp. 60-71.

Crowe, C. \& E. E. Meade. (2007). The Evolution of Central Bank Governance around the World. Journal of Economic Perspectives, 21(4), 69-90.

Cukierman, A., Webb, S. B. and Neyapti, B. (1992). Measuring the independence of central banks and its effects on policy outcomes. The World Bank Economic Review, 6, 353-398.

Eijffinger, S., Schaling, E. (1993). Central bank independence in twelve industrial countries. Banca Nazionale del Lavoro Quarterly Review, 184, 64-68.

Forder, J. (1996). On the measurement and assessment of 'institutional' remedies. Oxford Economic Papers, 48, $39-51$.

Goodfriend, M. (2002). Interest Rate Policy Should Not React Directly to Asset Prices, in Asset Price Bubbles: The Implications for Monetary, Regulatory and International Policies, (eds. William Hunter, George Kaufman and Michael Pomerleano), MIT Press, 427-444.

Greenspan, A. (2002). Opening Remarks, in Rethinking Stabilization Policy, Federal Reserve Bank of Kansas City, Kansas.

Groenewold, N. and Tang, S. H. K. (2004). The Asian financial crisis and the natural rate of unemployment: Estimates from a structural VAR for the newly industrializing economies of Asia. Pacific Economic Review, 9 (1), 45-64.

Grilli, V., Masciandaro, D., Tabellini, G. (1991). Institutions and policies. Economic Policy, 6, 341-392.

Gwartney, J., Lawson, R., Park, W. and Skipton, C. (2001). Economic Freedom of the World: 2001 Annual Report. Vancouver, BC: The Fraser Institute. [Online] Available: www.freetheworld.com.

Hayo, B. (1998). Inflation culture, central bank independence and price stability. European Journal of Political Economy, 14, $241-263$.

Hayo, B. and Hefeker, C. (2002). Reconsidering central bank independence. European Journal of Political Economy, 18, 653-676.

Kuttner, K.N., and Posen, A. S. (2001). Beyond Bipolar: A Three-Dimensional Assessment of Monetary Frameworks. International Journal of Finance and Economics, 6, 369-387.

Kydland, F.W., Prescott, E.C. (1977). Rules Rather Than Discretion: The Inconsistency of the Optimal Plans. Journal of Political Economy, 85, $473-491$.

Polillo, S. and Guillén, M. (2005). Globalization Pressures and the State: The Worldwide Spread of Central Bank Independence. American Journal of Sociology, 110(6), 1764-1802.

Posen, A.S. (1993). Why central bank independence does not cause low inflation. In: O'Brian, R. (Ed.), Finance and the International Economy, vol. 7. The Amex Bank Review Prize Essays. Oxford Univ. Press, Oxford, $40-65$.

Rogoff, K. (1985). The optimal degree of commitment to an intermediate monetary target. Quarterly Journal of Economics, 100, $1169-1190$.

Romer, D. (1993). Openness and Inflation: Theory and Evidence. Quarterly Journal of Economics, 108 (4), 869-903.

Walsh, C. E. (1997). Inflation and central bank independence: is Japan really an outlier? Bank of Japan Monetary and Economic Studies, 15, 89-117.

\section{Notes}

Note 1. For a detailed survey of this literature, see Berger, de Haan, and Eijffinger (2001) and Hayo and Hefeker (2002).

Note 2. Even though the CBC is not included in this study, its CBI score from Cukierman, Webb, and Neyapti (1992) is still applicable because its statutory independence has not changed since.

Note 3. The only implicit limitation on lending to the government is embedded in the government's public debt constraint. This is specified in Article 4 of the Public Debt Act: "The forecast outstanding of public debt extending more than one (1) year as taken out by the central and local governments, on the general budgets, special budgets, and in the form of extraordinary fund budgets beyond the operating funds and trust funds, shall 
not exceed forty-eight percent (48\%) of the average gross national product (GNP) of the previous three years as forecast by the Executive Yuan Directorate General of Budget."

Note 4. Those are current OECD countries whose GDP deflator data are available, including Australia, Belgium, Canada, Denmark, Finland, France, (West) Germany, Greece, Iceland, Ireland, Italy, Japan, Korea, Luxembourg, Mexico, Netherlands, New Zealand, Norway, Portugal, Spain, Sweden, Switzerland, UK, and USA.

Note 5. http://www.bas-association.org.tw/catalog/arts/09401034.pdf, unpublished internal research, in Chinese.

Note 6. These include the general elections of the President in 1996, 2000, 2004, and 2008, and the elections of the legislators of the Legislation Yuan in 1980, 1983, 1986, 1989, 1992, 1995, 1998, 2001, 2004, and 2008.

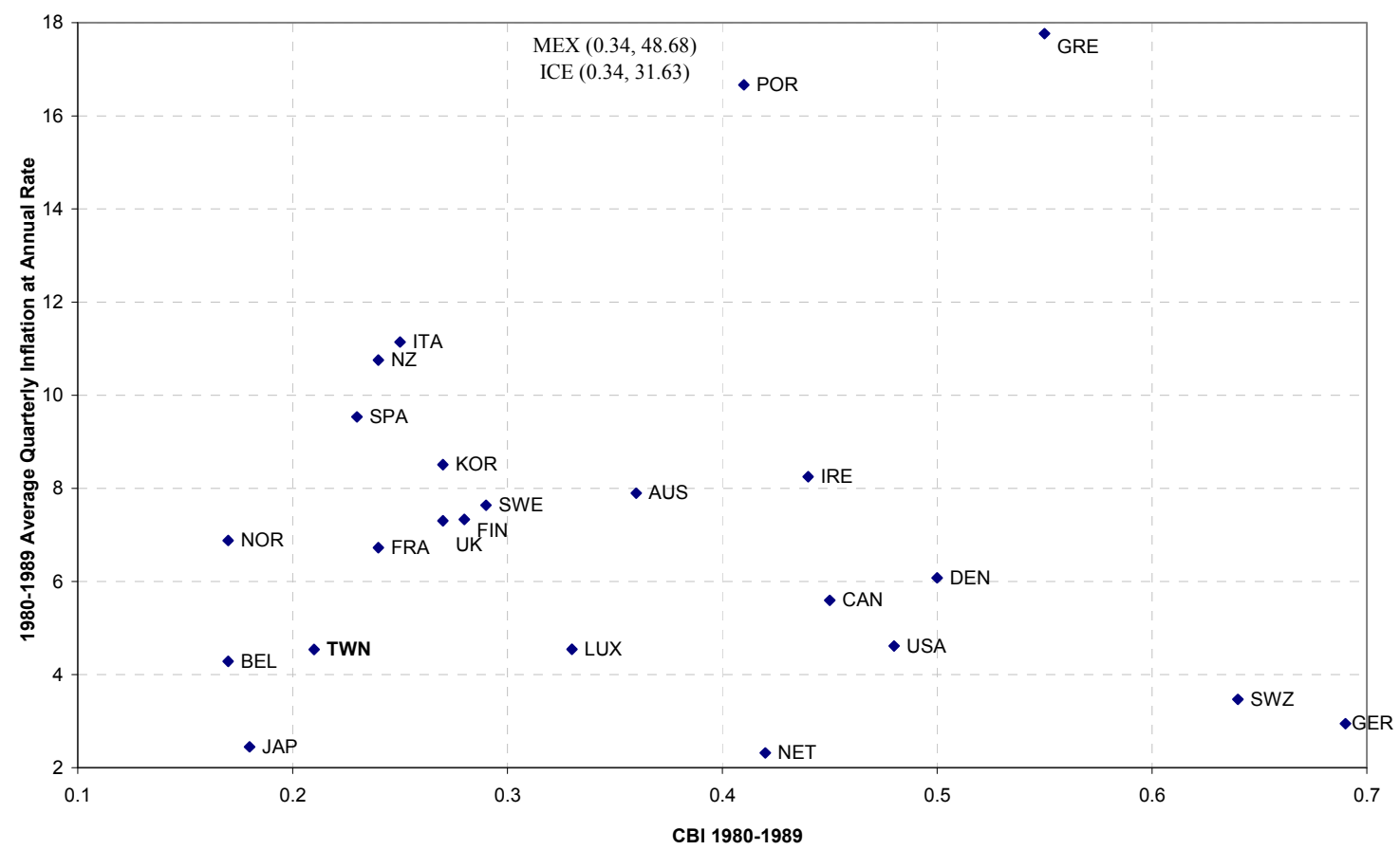

Figure 1. Average Inflation against CBI (1980-1989)

** See Endnote 4 for the countries included in this figure 


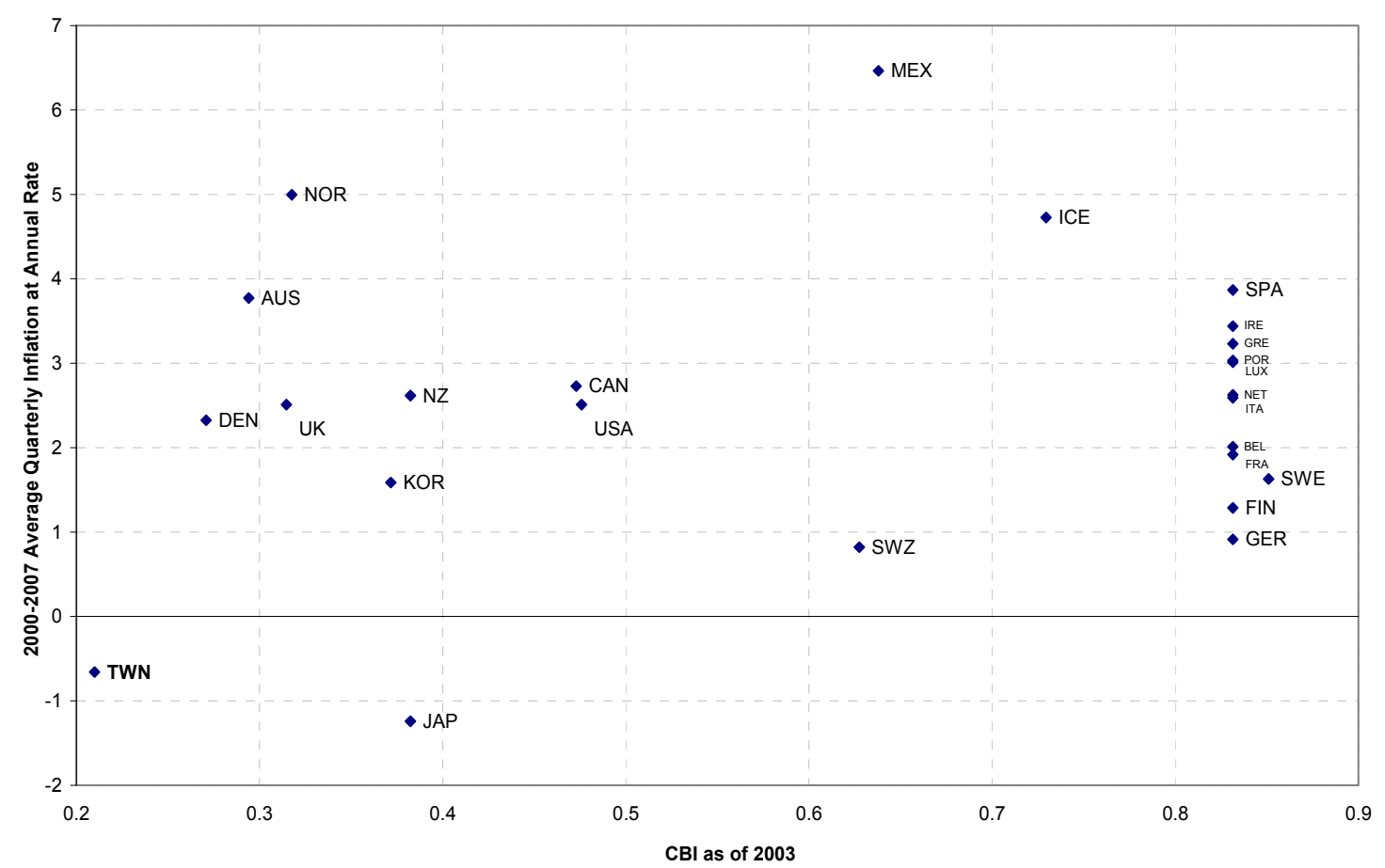

Figure 2. Average Inflation against CBI (2000-2007)

** See Endnote 4 for the countries included in this figure.

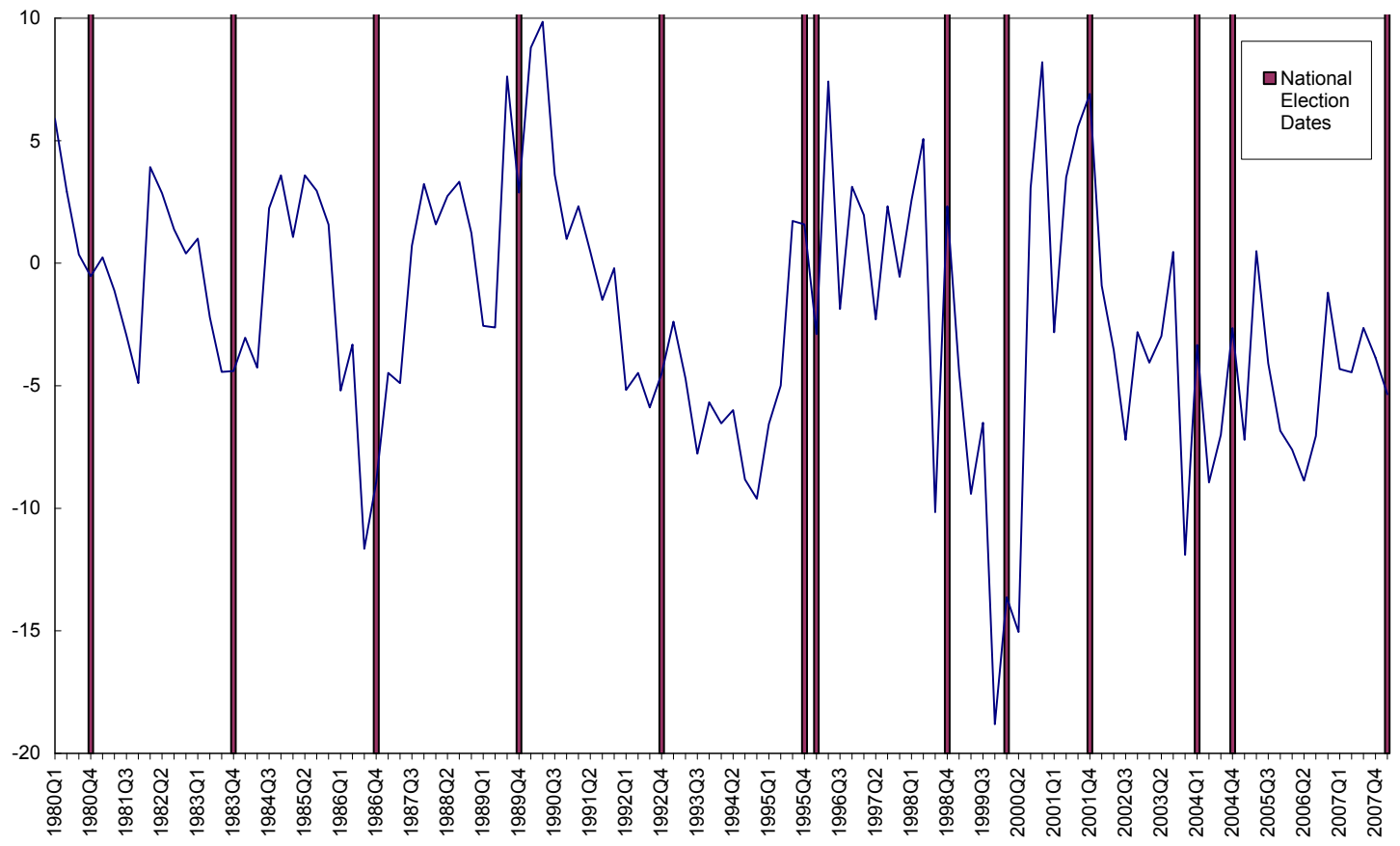

Figure 3. Growth rate ( $\%$ change from the same quarter a year ago) of government expenditure/GDP ratio 